artigo ] CAROLINE HADLICH | ANNA LUIZA MORAES DE SA CAVALCANTI

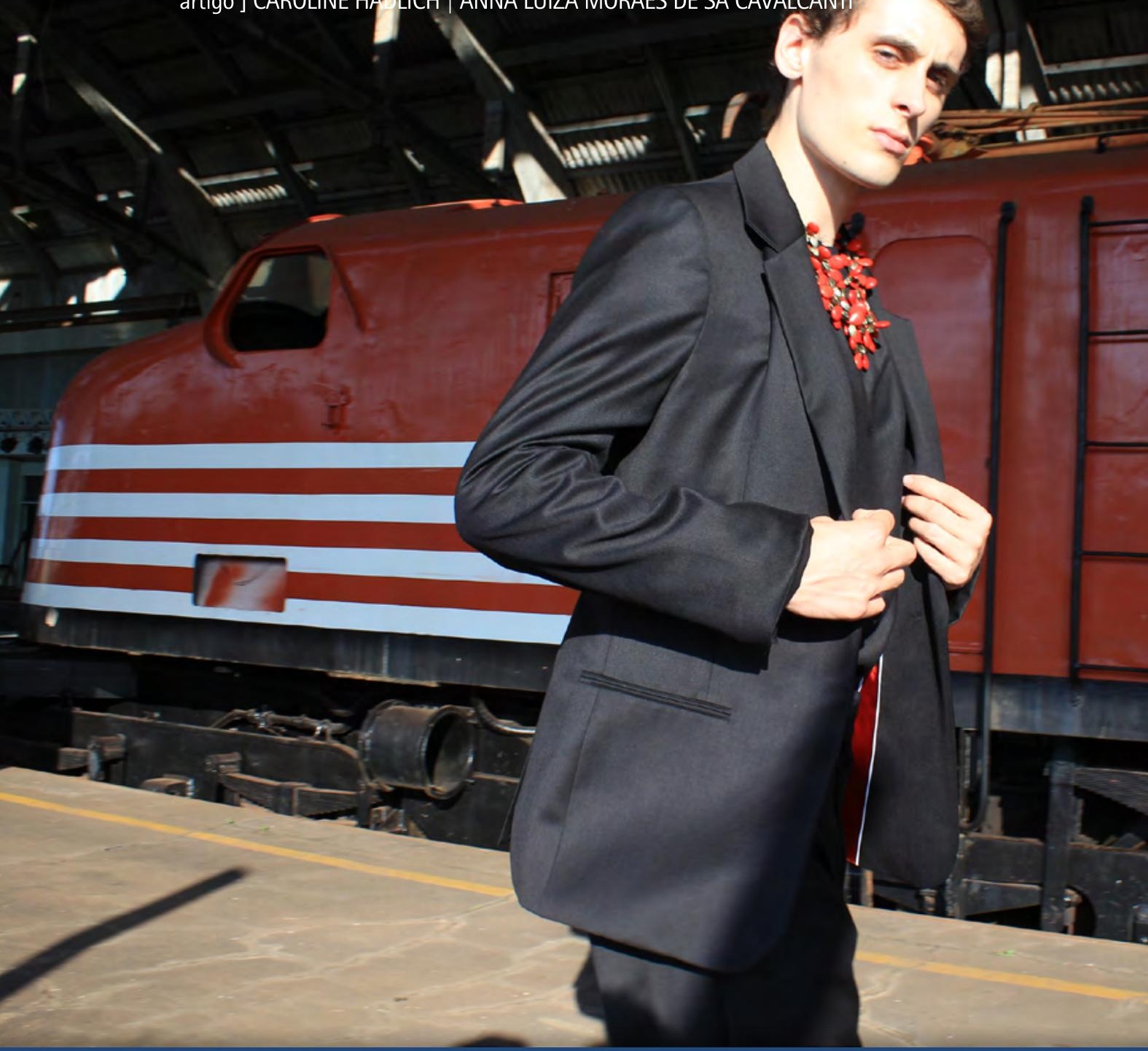

\title{
Gestão do design para a sustentabilidade no terceiro setor: uma proposta para a Rede Feminina de Combate ao Câncer de Indaial
}

Design management for sustainability in the third sector: a proposal for the Women's Network to Combat Cancer of Indaial 


\section{[CAROLINE HADLICH]}

Mestre em Design. Coordenadora e professora do curso de Design

- Moda da Uniasselvi

E-mail: hadlichcarol@gmail.com

\section{[ANNA LUIZA MORAES DE SA CAVALCANTI]}

Mestre em Industrial Design. Professora adjunta da graduação e do mestrado profissional em Design da Univille

E-mail: anna.cavalcanti08@gmail.com

[resumo] 0 artigo relata o resultado de uma pesquisa feita no Mestrado Profissional em Design da Univille. 0 objetivo desta investigação foi articular por meio da gestão de design um processo de cooperação entre a ONG Rede Feminina de Combate ao Câncer de Indaial, as confecções da região de Indaial, o Centro Universitário Leonardo da Vinci e a Fundação Indaialense de Cultura. Esta articulação visa contribuir para a sustentabilidade da ONG, para tanto foi realizada uma pesquisa descritiva, com levantamento e análise dos dados para fundamentação, e uma exploratória, por meio de métodos e técnicas do design thinking. A pesquisa levou à elaboração de uma proposta de gestão de design que possibilite sua replicação em outras RFCC e demonstre a articulação.

\section{[palavras-chave]}

\section{inovação social, gestão do design,} sustentabilidade.

[abstract] The article reports the result of a research done in the Professional Master in Design of Univille. The objective of this research was to articulate, through design management, a cooperation process between the NGO Women's Network to Combat Cancer of Indaial, the confections of the Indaial region, the Leonardo da Vinci University Center and the Indaialense Foundation of Culture. This articulation aims to contribute to the sustainability of the NGO, for which a descriptive research was carried out, with data collection and analysis for foundation, and an exploratory, through methods and techniques of design thinking. The research led to the elaboration of a design management proposal that allows its replication in other NGOs and demonstrates the articulation.

[keywords] social innovation, design management, sustainability. 
Introdução

0 município de Indaial, localizado no estado de Santa Catarina, tem como principal atividade industrial as confecções têxteis, que produzem artigos de vestuário, sejam em malha ou tecido plano. 0 setor de confecções soma 384 estabelecimentos, ou seja, 41\% da indústria.

A Rede Feminina de Combate ao Câncer (RFCC), considerada uma das maiores organizações não governamentais (ONG) do país, foi fundada no Brasil em 1946, porém, em Santa Catarina iniciou suas atividades em 1961. Como entidade sem fins lucrativos, busca por meio de um grupo de voluntárias atender enfermos e, desde sua fundação, presta relevante trabalho voluntário, demonstrando a importância da prevenção do câncer, sempre com ênfase no câncer do colo do útero e no de mama.

A RFCC de Indaial, fundada em 1990, tem atualmente aproximadamente 80 voluntárias. 0 atendimento ao público prioriza a realização da coleta de material para o exame Papanicolau de maneira gratuita e drenagem linfática em pacientes mastectomizadas, desde que encaminhadas pelo médico. Oferece também atendimento voluntário dos seguintes profissionais da saúde: ginecologista, psicólogo, fisioterapeuta e nutricionista.

Para manter a estrutura de funcionamento, a entidade conta apenas com o rendimento do brechó de roupas, acessórios e materiais novos e usados, todos doados pela comunidade e empresas. Atualmente, a RFCC tem um ateliê, onde os produtos são confeccionados de acordo com a demanda (datas comemorativas como dias dos pais, dia das mães, Páscoa, Natal, dentre outras). Os trabalhos também são feitos conforme encomendas das próprias voluntárias ou público que frequenta o estabelecimento, seja para fazer exames, drenagem linfática ou adquirir produtos no brechó.

A equipe de trabalho tem atualmente seis voluntárias com conhecimentos e habilidades especificas para desenvolver várias atividades como: costura manual e à máquina, bordado, pintura, dentre outras. Destaca-se a colaboração entre as voluntárias no desenvolvimento destes trabalhos, pois para concluir um produto é necessária a atuação de várias pessoas.

A articulação foi realizada com o Centro Universitário Leonardo da Vinci (Uniasselvi), na representação da acadêmica Caroline Hadlich, atualmente coordenadora do curso de Design-Moda da Uniasselvi. 0 curso conta com laboratórios de costura e acabamento, de modelagem, de criatividade, de desenho, de informática com softwares específicos e de fotografia, que foram disponibilizados para o desenvolvimento deste projeto.

Outra entidade envolvida foi a Fundação Indaialense de Cultura Prefeito Victor Petters, instituída no final de 1987, e que tem como responsabilidade 
propiciar a arte local e reconhecer os atrativos artísticos do município. Nas suas dependências acontecem exposições de artes visuais e plásticas, espetáculos teatrais, de dança, de música e patinação artística, feiras, festivais e seminários, divulgação das tradições, apresentações de bandas e orquestras, desfiles de rua, cursos e oficinas, noites culturais e recitais, dentre outras atividades ligadas à cultura. Também oferece cursos e oficinas de artes plásticas, dança, música, folclore, teatro, oficinas e artesanato.

Dessa maneira, a articulação política proposta entre os atores envolvidos descritos anteriormente, apresenta-se como alternativa viável para coordenar um processo que integra atores sociais distintos. 0 processo compreende conhecimentos do design e da gestão estabelecendo um diálogo entre as empresas têxteis do município de Indaial, a ONG, a universidade e a Fundação Cultural. A finalidade é propiciar a manutenção economicamente sustentável da RFCC a partir do reaproveitamento dos resíduos têxteis das confecções, por meio da capacitação promovida pela universidade e a promoção e valorização das ações desenvolvidas pela RFCC em parceria com a Fundação Indaialense de Cultura.

\section{Sustentabilidade e economia criativa}

As indústrias de confecção geram anualmente toneladas de resíduos sólidos que ainda são descartados em aterros industriais. De acordo com Freitas, Silva e Peccini (2012), nas indústrias de confecções o reaproveitamento dos materiais utilizados na produção de roupas ganha destaque no artesanato, contribuindo economicamente e socialmente para o desenvolvimento das comunidades ou, ainda, resíduos inevitavelmente gerados podem ser reutilizados, recuperados ou reciclados dentro da própria indústria.

Considerando o curto ciclo de vida dos produtos oriundos das empresas de confecção, por se tratar de produtos efêmeros devido aos conceitos e ciclos da moda, este segmento produz um significativo volume de resíduos sólidos nos processos de produção. A utilização destes resíduos sólidos constitui uma forma de geração de renda para comunidades carentes, através de artesanato. De acordo com Mesacasa (2012), com o aproveitamento do tecido para confecção de novos produtos, o ciclo de vida do material não é interrompido, pois este será transformado em produto com fins nobres para o consumidor.

0 Programa do Artesanato Brasileiro (PAB) compreende e define artesanato como "uma das mais ricas formas de expressão da cultura e do poder criativo de um povo. Na maioria das vezes, é a representação da história de sua comunidade e a reafirmação da sua autoestima" (PAB, 2012, p. 7). Nesse sentido, no presente estudo o artesanato seria o fruto de uma relação entre as indústrias têxteis, na forma de seus resíduos têxteis e a RFCC, uma vez que uma das grandes culturas da região do Vale do Itajaí, onde se encontra a cidade de Indaial, é a costura. 
Portanto, o reaproveitamento dos resíduos têxteis, somados à capacidade de costura dos voluntários, pode gerar um ativo de valor ambientalmente correto, tendo em vista que o resíduo não seria descartado de maneira incorreta, mas serviria de matéria-prima para novos produtos artesanais.

Borges (2011, p. 137) defende que "a aproximação entre designers e artesãos é, sem dúvida, um fenômeno de extrema importância pelo impacto social e econômico que gera e por seu significado cultural". 0 design pode intervir de forma a propiciar produtos esteticamente desejáveis, contribuir com soluções para o processo de criação e desenvolvimento, além de orientar a divulgação e comunicação desse artesanato, que neste projeto teve a parceria da Fundação Cultural do município de Indaial.

Os ecoprodutos surgiram para nutrir a reaplicação de materiais, buscando reduzir o impacto ambiental causado pela produção industrial em larga escala. Segundo Araújo,

0 produto ecológico é capaz de despertar a consciência eco-social da comunidade e educar ambientalmente quem o produz e quem o consome. 0 Brasil é o país mais rico do mundo em matérias-primas naturais renováveis (mais de $20 \%$ da biodiversidade planetária), tem um lixo abundante e ainda pouco aproveitado (245 mil toneladas/dia), além de milhões de toneladas de resíduos agrícolas e industriais sem qualquer uso. Em suma, o país reúne todas as condições para ser um verdadeiro celeiro de ecoprodutos e materiais reciclados, gerando emprego e levando cidadania a milhões de pessoas, tornando-se um modelo de sustentabilidade para outras nações. Tecnologia, know-how e criatividade não faltam para isso (ARAÚJ0, 2001).

Os ecoprodutos geram emprego e renda; consequentemente, promovem a cidadania e fazem parte da economia criativa, cujos modelos de negócios ou gestão se originam em atividades, produtos ou serviços desenvolvidos a partir do conhecimento, criatividade ou capital intelectual de indivíduos com vistas à geração de trabalho e renda (SEBRAE, 2016). Portanto a economia criativa pode ser encarada como uma fonte transformadora do mundo, pois traz benefícios econômicos e o desenvolvimento social, além de proporcionar qualidade de vida e valorização dos traços culturais de cada localidade, e estimula o crescimento sustentável.

A economia criativa ganha destaque como originador de riqueza e transformações sociais. Trata-se de um conceito amplo e que ganha cada vez mais espaço. De acordo com Santos-Duisenberg (2008), ela surge como uma mudança de método, que sai do mais convencional, centrado no comércio e na fabricação industrial, para uma abordagem mais multi- 
disciplinar, que trabalha com economia, cultura e tecnologia, centrada em produtos e serviços criativos.

Desta maneira, o talento individual, a criatividade e a inovação são peças-chave em iniciativas nas quais a economia criativa está inserida, pois integra esforços artísticos de uma empresa ou pessoa.

De acordo com Manzini (2008), define-se criatividade como a capacidade de reorganizar elementos já existentes em novas combinações, e esses grupos podem ser definidos como uma comunidade criativa, que de maneira colaborativa inventa e aprimora soluções inovadoras para novos modos de vida.

0 Portal Brasil (2012) destaca que o empreendedorismo social significa um negócio que oferece desenvolvimento para a sociedade e é lucrativo. Empresas sociais, por meio do empreendedorismo social, buscam soluções para problemas da sociedade, auxiliando a população excluida do mercado habitual, combatendo assim a pobreza e diminuindo a desigualdade. Desta maneira, tem-se como objetivo principal dos empreendimentos e negócios sociais a geração de renda e qualidade de vida, pois são economicamente rentáveis.

Newbigin (2010) afirma que o governo tem um papel importante no processo de cultivar a criatividade, porém a economia se move conforme 0 movimento criativo das pessoas, e elas, por sua vez, movem-se de acordo com o ritmo das culturas nas quais estão inseridas. Muitos setores estão se movendo rapidamente, o que é o resultado de uma mistura de políticas públicas de sucesso, criatividade individual e patrimônio cultural. E por esse motivo, a Secretaria da Economia Criativa (SEC) recebeu a tarefa de fomentar, estimular e implementar práticas de desenvolvimento que tivessem a cultura como ponto central, apoiando profissionais e empreendimentos criativos desde abril de 2011, quando entrou em funcionamento (MADEIRA, 2014).

Lala Deheinzelin, co-criadora do arranjo produtivo denominado Fluxonomia 4D (figura 1), através da ferramenta visão 4D observa sistematicamente quatro dimensões - Cultural, Ambiental, Social e Financeira - buscando 4 economias: Criativa, Compartilhada, Colaborativa e Multivalor (ALVES, 2015). A economia criativa ocorre na influência da cultura, quando o valor não está no material. A economia compartilhada ocorre na influência tecnoambiental, quando se compartilha infraestruturas disponíveis. A economia colaborativa observa o modelo de gestão, influência social que gera valor para os outros. A economia multivalor ocorre na influência financeira, quando se verifica a sustentabilidade do projeto desde os recursos monetários até o âmbito social, ambiental, financeiro e cultural. 
Figura 1: Fluxonomia 4D

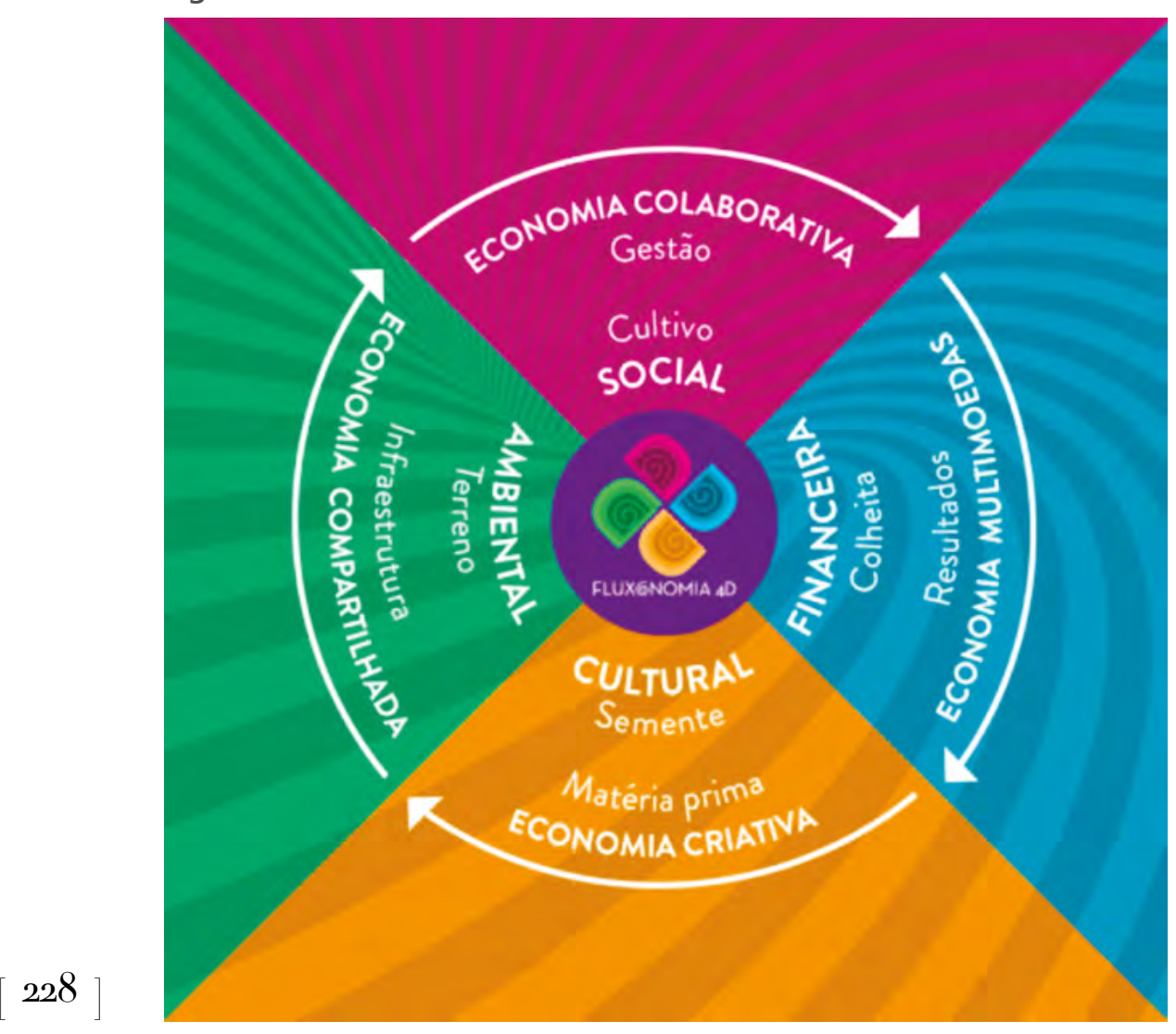

Fonte: OKABE, 2016.

Ao observar e compreender os fluxos descritos é possivel perceber que de pouco valem recursos financeiros e ambientais se não houver o conhecimento das pessoas. Sendo assim, esse sistema proporcionará a passagem de uma economia de consumo, insuficiência e disputa para a economia do cuidar e colaborar. Com essa transição será possivel visualizar novas oportunidades futuro desejável para o novo mundo.

Ao fomentar as práticas e empreendimentos criativos e incentivar a associação de vários pequenos, de acordo com Deheinzelin (2013) pode-se ganhar escala; e a integração de muitos, pequenos e diversos, também é interessante para uma etapa de transição. A diversidade e o hibridismo são pontos importantes para a economia criativa. Reconhecer o seu meio, a sua gente como patrimônio também é uma grande oportunidade. Não basta somente desenvolver a cultura, mas sim desenvolver o país e seu território por meio da cultura.

Desta maneira, as comunidades criativas evoluem e se tornam empreendimentos sociais e, de maneira colaborativa, compartilham conhecimento e formam uma rede de pessoas ativas e colaborativas. 


\title{
Desenvolvimento da proposta de gestão
}

Para compreender as expectativas da RFCC, a participação da FIC e a colaboração das empresas têxteis participantes do projeto, foi realizada uma pesquisa de abordagem qualitativa exploratória por meio de entrevistas. Conforme Gil,

\begin{abstract}
Este tipo de entrevista é o menos estruturado possivel e só se distingue da simples conversação porque tem como objetivo básico a coleta de dados. 0 que se pretende com entrevistas deste tipo é a obtenção de uma visão geral do problema pesquisado, bem como a identificação de alguns aspectos da personalidade do entrevistado (GIL, 1991, p. 111).
\end{abstract}

0 método de trabalho foi estruturado com base na abordagem do Design Thinking, composto por 4 etapas: Imersão, Análise, Ideação e Entrega, as quais foram relacionadas com os objetivos deste trabalho; e do Design Participativo que, segundo Schuler e Namioka (1993), favorece a participação dos atores no desenvolvimento das soluções. Sanders (2002) afirma que todas as pessoas têm algo a oferecer ao processo de design e workshop para encontrar as soluções e aplicações, a fim de por em prática os resultados da investigação. Em experiências participativas o usuário é um componente crítico no processo e as pessoas participam de maneira direta 229 ] e proativa no desenvolvimento; essa é uma maneira de compreender o que o usuário quer, quando quer e como quer.

Na etapa de Imersão foi desenvolvida a pesquisa de campo qualitativa exploratória com a finalidade de coletar informações por meio de entrevistas com todos os atores identificados para o projeto. Todo projeto foi submetido ao comitê de ética da Univille, com o parecer número 2.064.408 na Plataforma Brasil'.

A imersão aprofundada serviu para a identificação e reconhecimento dos atores: conhecer as necessidades da RFCC de Indaial; levantar as empresas de confecções que geram resíduo têxtil no municipio de Indaial e fazer uma avaliação das características dos resíduos; entender a participação da FIC.

A fim de conhecer as necessidades da RFCC de Indaial, bem como as habilidades e competências do grupo de voluntárias, foram realizadas entrevistas estruturadas por meio das quais buscou-se conhecer suas experiências individuais, identificar suas atribuições no grupo, bem como suas dificuldades, desejos, trabalhos já realizados e conhecimentos a respeito de iniciativas semelhantes. Participaram das entrevistas quatro voluntárias atuantes no "Artesanato Rosa", ateliê de trabalhos manuais da RFCC de Indaial 
Posteriormente foram identificados e entrevistados os proprietários de oito confecções para participarem do projeto: Cheia de Laço Confecções Ltda - ME; Edla Baucke - Epp; Finamor Confecções Ltda - Epp; Oscar dos Reis e Cia Ltda; Poli Confecções Eireli; Protótipo Indústria e Comércio de Confecções Ltda; Schöne Mode Ltda - ME; Tonatua Confecções Ltda. As confecções participantes foram selecionadas a partir de uma análise dos produtos e matérias-primas utilizadas, para obter uma maior diversidade de resíduo têxtil.

Finalizando a etapa de imersão, para conhecer a atuação da FIC foi realizada uma entrevista com as diretoras da entidade para identificar as iniciativas fomentadas pela Fundação, parcerias realizadas, programas, cursos e possiveis contribuições da instituição para o projeto, bem como a viabilidade da participação da RFCC com seu trabalho em eventos realizados pela FIC.

A segunda etapa da abordagem Design Thinking corresponde à Análise. De acordo com Vianna et al. (2012), após as etapas de levantamento de dados da fase de imersão, os próximos passos são a análise e sintese das informações coletadas. Para tal, os insights são organizados de maneira a se obter padrões e a criar desafios que auxiliem na compreensão do problema.

Ao analisar todas as respostas das voluntárias da RFCC de Indaial, observa-se que cada voluntária possui uma atribuição no grupo e suas habilidades são levadas em consideração na divisão de tarefas. Os produtos confeccionados são diversificados e metade das voluntárias não percebe a necessidade de aprender uma nova técnica específica. Outro detalhe importante é a habilidade que o grupo possui em desenvolver trabalhos a partir do resíduo têxtil.

Na sequência, foram também estruturadas as entrevistas com os oito proprietários das confecções. Ao analisar as respostas, observou-se que 0 percentual de resíduo gerado pelas empresas é muito alto e que não existe um programa para o reaproveitamento em nenhuma delas, somente descarte e comercialização. A resposta foi extremamente positiva ao serem questionados a respeito da possibilidade de uma parceria para a doação de resíduos para a RFCC.

Por fim, foram também analisadas as entrevistas com as diretoras da FIC e foi constatado que existe um potencial de colaboração com a RFCC, principalmente na divulgação e comercialização dos produtos na Feira de Rua Bummeln, evento que acontece mensalmente na avenida Beira Rio do município. 
A Uniasselvi apresenta-se aqui representada pela pesquisadora, cuja proposta de projeto no mestrado profissional foi articular as diversas instituições identificadas e desenvolver uma gestão de design que contribuísse para a sustentabilidade da RFCC.

Após a identificação e reconhecimento dos atores envolvidos nesta pesquisa, foi possivel sistematizar um processo para uma articulação entre as entidades envolvidas, apresentado por meio de um infográfico (figura 2) que mostra a relação, atuação e envolvimento dos atores e de que forma é possivel construir a parceria entre eles.

Figura 2: atuação e envolvimento dos atores

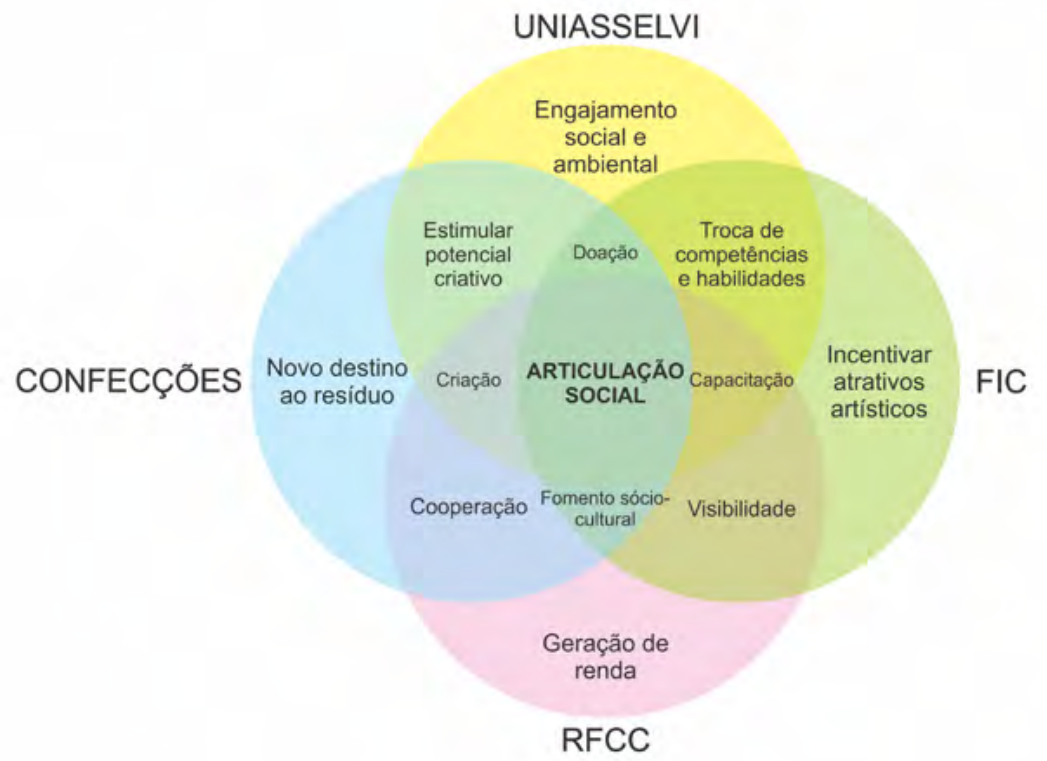

Fonte: as Autoras, com base nas entrevistas realizadas em 2017 com representantes da RFCC, da FIC e das empresas de confecção.

Nesta etapa também foi realizado um estudo relacionado aos resíduos disponíveis, material disponibilizado à pesquisadora pelas empresas de confecção: em média $500 \mathrm{~g}$ de resíduo têxtil de diferentes características, de acordo com os produtos em fabricação. Os materiais foram identificados e separados buscando alternativas de artefatos possíveis de serem desenvolvidos com eles e dos conhecimentos especificos das voluntárias do RFCC.

Importante ressaltar o interesse por parte das empresas em buscar um novo destino ao resíduo têxtil, além de estimular o potencial criativo na parceria com a Uniasselvi e a cooperação com a RFCC. Essa receptividade demonstrada nas entrevistas foi sobretudo pela oportunidade de oferecer um novo destino ao resíduo gerado. 
Os resíduos fornecidos tinham composições e gramaturas diferentes, coloração e estampas diversificadas, dimensões desiguais e tecidos variados, conforme se observa na figura 3.

Figura 3: resíduos têxteis disponibilizados pelas confecções

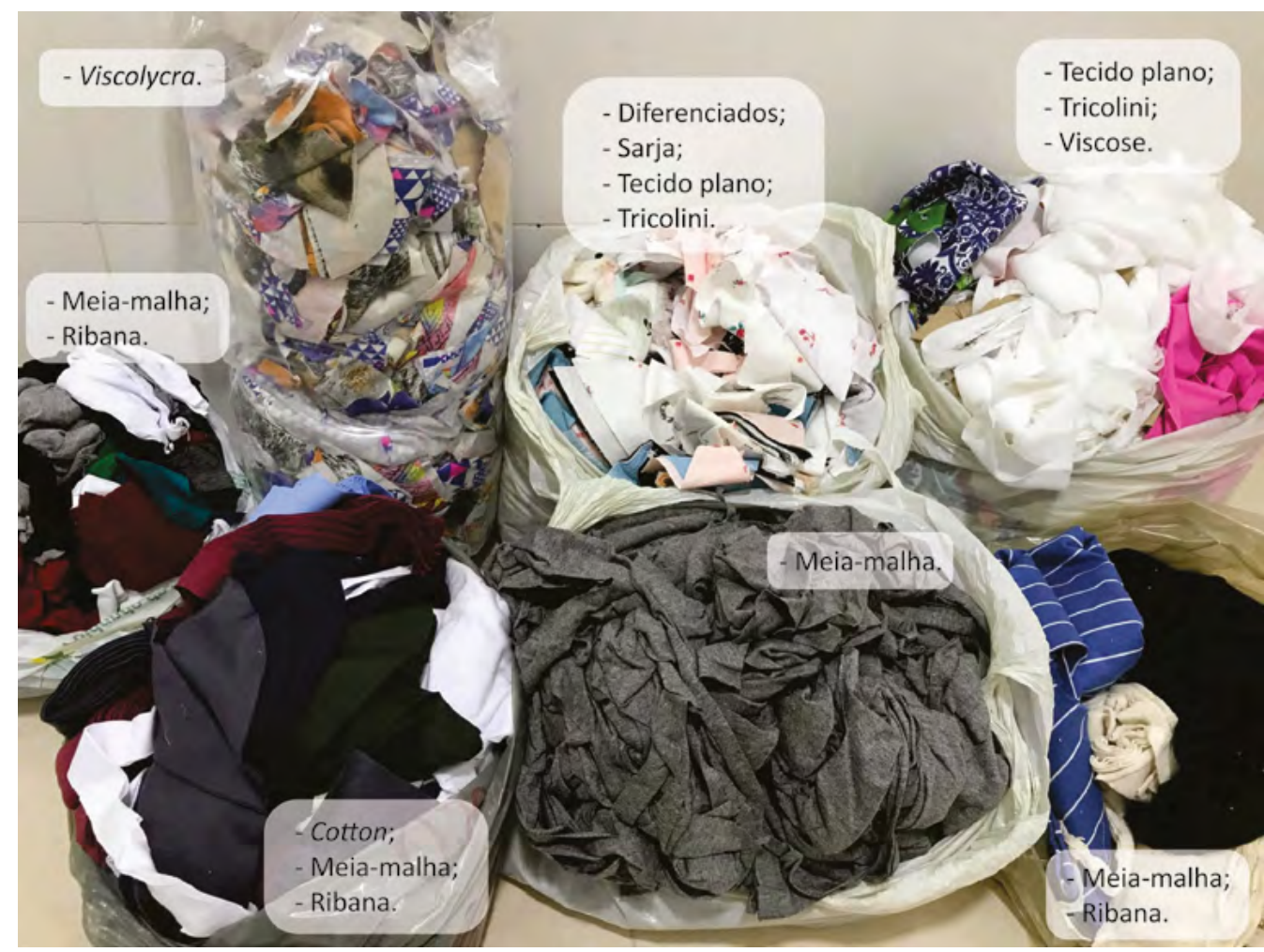

Fonte: fotografia produzida pelas Autoras em 2017.

A diversificação do material ampliou a possibilidade de estudos sobre a utilização do resíduo, porém as dimensões poderiam trazer dificuldades para a confecção dos novos produtos. Todos os materiais foram identificados, selecionados e separados de acordo com dimensões e características: cor, gramatura e estampa.

A fase da Ideação, de acordo com Vianna et al. (2012), tem como intuito gerar ideias inovadoras para o tema do projeto e, para isso, utilizam-se as ferramentas de síntese criadas na fase de Análise para estimular a criatividade e gerar soluções que estejam de acordo com 0 contexto do tema trabalhado.

Foram utilizadas as ferramentas de mapa mental respondendo as seguintes questões: o que é? Quando usar? Como aplicar? (figura 4). 
Figura 4: mapa mental

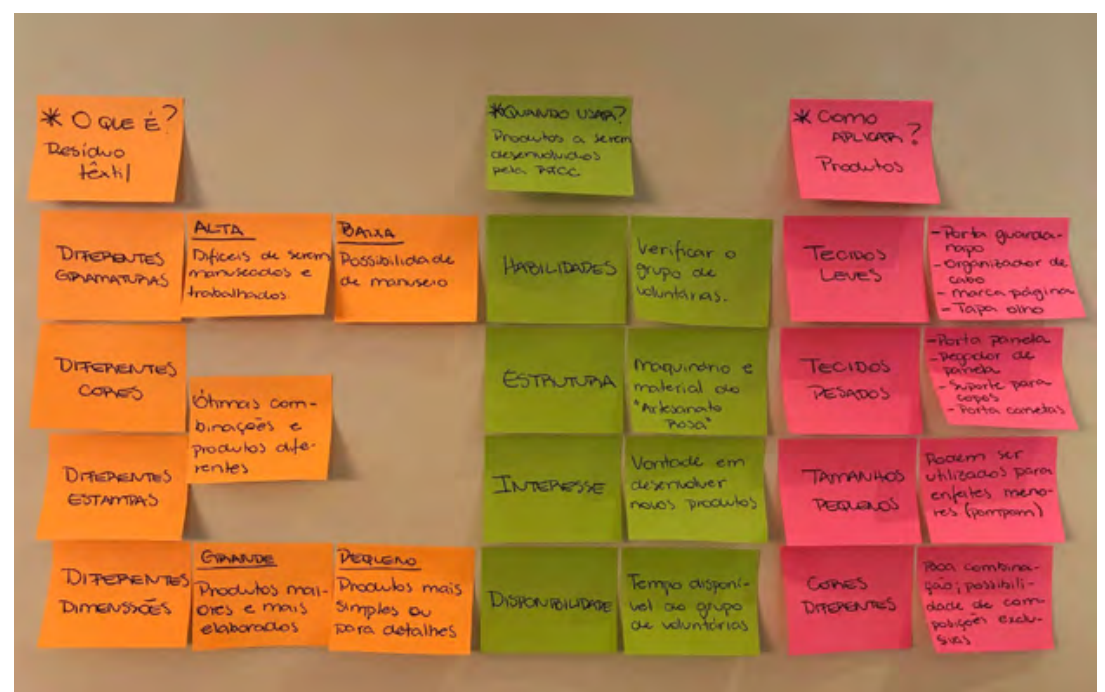

Fonte: fotografia do mapa mental produzida pelas Autoras em 2017.

A partir do mapa mental foi realizado um brainstorming para a seleção de algumas referências visuais pesquisadas na internet e a geração de alternativas. Todas as indicações e discussões realizadas nesta etapa foram importantes e facilitaram o desenvolvimento do processo. A discussão gerou um painel visual para a geração de alterativas e posterior prototipagem, conforme apresenta a figura 5.

Figura 5: painel visual apresentando (1) pompom de malha para enfeites de porta, chaveiros e artigos decorativos; (2) porta-copos; (3) tapa-olho; (4) porta-caneta e lápis; (5) porta-guardanapo; (6) caixa porta-objetos; (7) marca-páginas; (8) organizador de cabos; (9) pegador de panela.

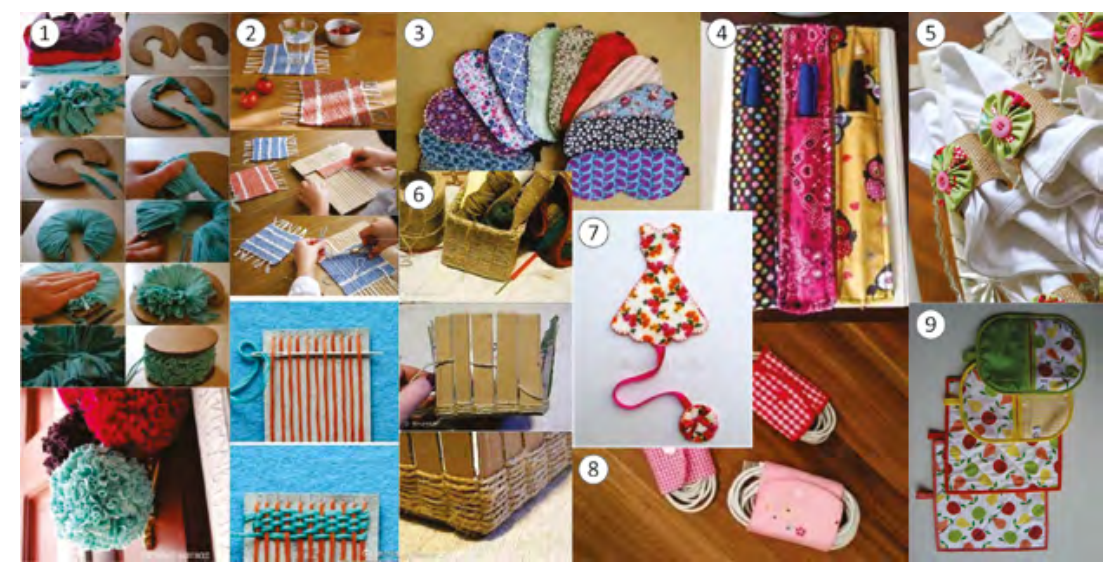

Fonte: painel visual composto pelas Autoras a partir de imagens coletadas na internet em 2017.

Como resultado do brainstorming, optou-se por desenvolver o tapa-olho e dois modelos de marca-páginas, imagens 3 e 7 da figura 10, em virtude da dimensão dos resíduos cedidos pelas confecções e da facilidade e agilidade para confeccionar esses artigos, além de serem produtos diferentes dos que usualmente o grupo já confecciona. 
Em seguida iniciou-se a fase de teste do material (modelagem e costura) com o resíduo cedido, geração de alternativas de produtos, identificação das necessidades da RFCC e as restrições que o material cedido apresentava.

A diversidade de resíduos se mostrou um ponto positivo, possibilitando diversas experimentações; porém, suas dimensões limitaram o processo criativo, pois muitos produtos não puderam ser desenvolvidos.

A gramatura também foi outro obstáculo, pois tecidos de maior peso e grossos são mais difíceis de serem manipulados e não possuem a mesma maleabilidade que tecidos e malhas leves.

Todos os protótipos e testes foram realizados e confeccionados nos laboratórios do curso de Design-Moda da Uniasselvi (Laboratório de Criatividade, Ateliê de Costura e Laboratório de Acabamento), que contam com máquinas de costura e talhação, tesouras, agulhas, linhas e demais materiais de apoio necessários para confecção dos protótipos (figura 6).

Figura 6: prototipação dos produtos: marca-páginas

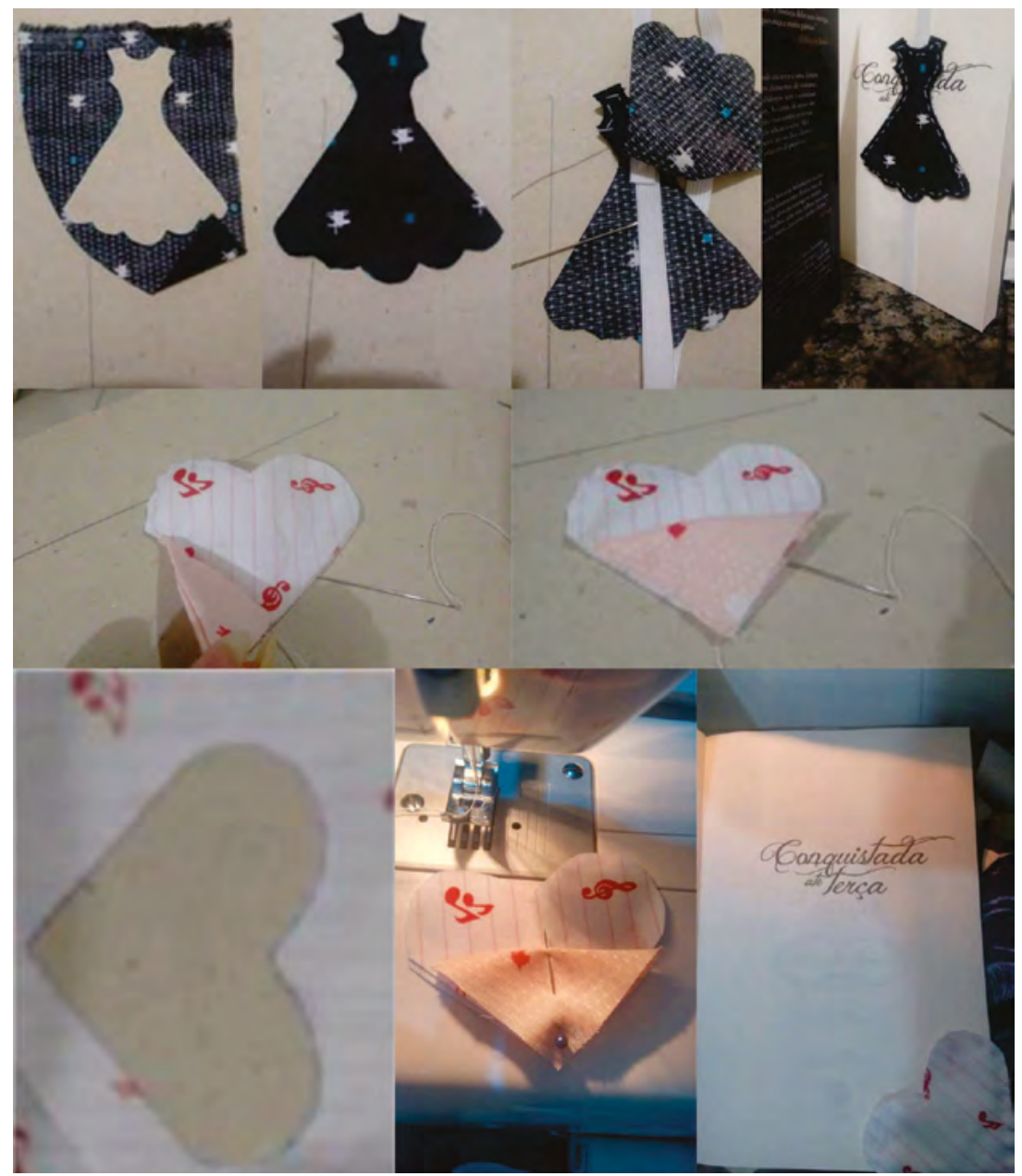

Fonte: fotografia dos protótipos produzida pelas Autoras em 2017. 
Os modelos prototipados correspondem a um marca-página em formato de vestido, fixado com elástico de $1 \mathrm{~cm}$ de largura, tamanho $12 \mathrm{~cm}$ $x 6 \mathrm{~cm}$, que identifica a página quando posicionado no meio do livro, entre páginas; o outro, em formato de coração, tamanho $10 \mathrm{~cm} \times 6 \mathrm{~cm}$, identifica a página quando posicionado no canto da página do livro. Também foi prototipada uma viseira "tapa-olhos" tamanho $19 \mathrm{~cm} \times 7 \mathrm{~cm}$, utilizando 0 resíduo cedido pelas empresas acrescido de aviamentos como enchimento de fibra e elástico com $1 \mathrm{~cm}$ de largura. Os materiais extras foram da RFCC.

A figura 7 apresenta estes modelos confeccionados que serviram de amostras para a realização das próximas etapas do processo.

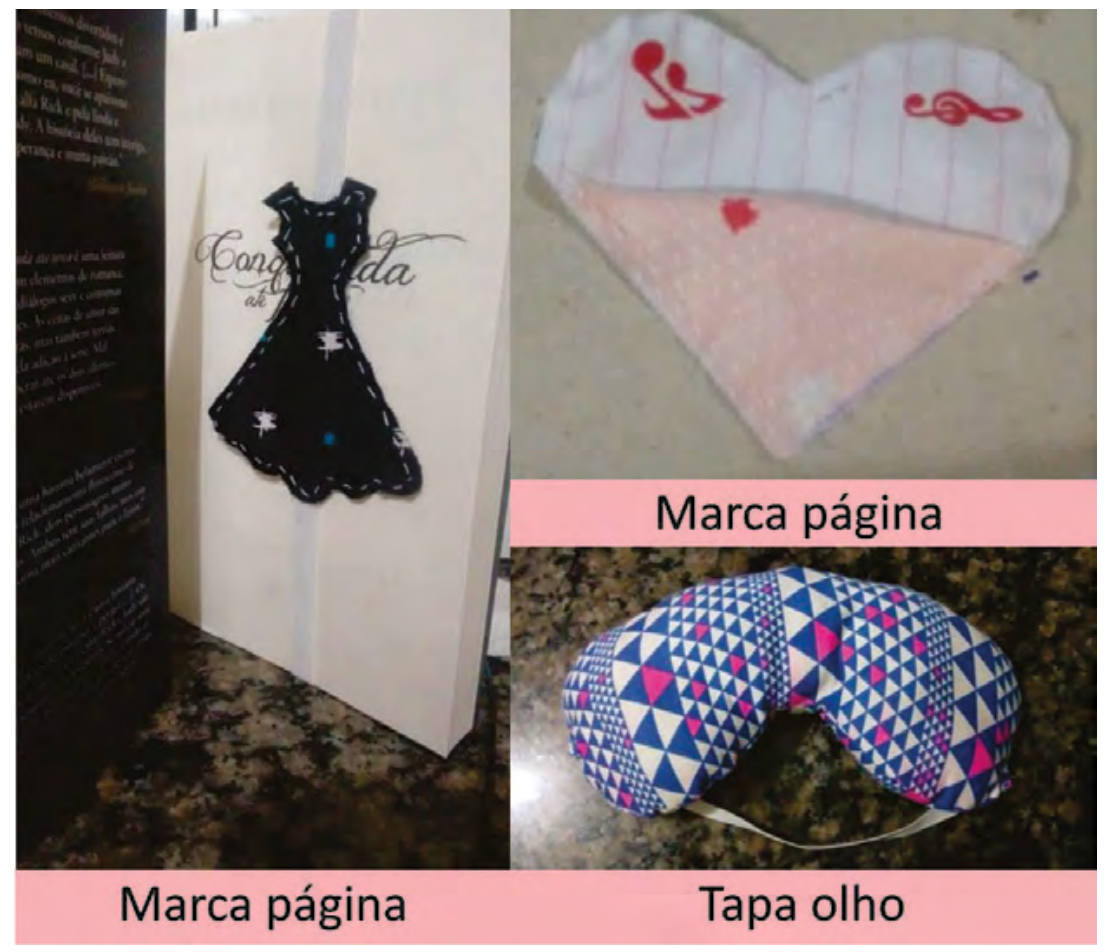

Fonte: fotografia produzida pelas Autoras em 2017.

Após selecionados os produtos a serem desenvolvidos pelas voluntárias da RFCC, aconteceu o workshop. Conforme Pinheiro e Alt (2011), a pluralidade do grupo gera um potencial criativo bem maior que aquele que surge individualmente, além de envolver o participante. De acordo com Santa Rosa (2013), todas as ponderações são avaliadas com a condicionante de serem executadas ou não. 0 Design Participativo também foi uma abordagem importante neste processo pois, conforme afirmam Schuler e Namioka (1993), a participação do usuário é indispensável para compreender a ânsia existente no grupo, possibilitando voz ativa no desenvolvimento das soluções. Sanders (2012) corrobora enfatizando que a participação direta e ativa das partes interessadas no processo de desenvolvimento torna as ideias mais criativas e as pessoas se beneficiam delas.

0 workshop que foi realizado na RFCC de Indaial (figura 8) teve como base Santa Rosa (2013), que relata que essas atividades práticas possibilitam o envolvimento do participante, e que suas considerações devem ser 
avaliadas e eventualmente colocadas em prática. A metodologia utilizada no workshop visa melhorar a prática do usuário com novas soluções; ele é coautor do processo e sua participação é determinante para o sucesso do projeto. 0 método de trabalho teve como cerne criar novas maneiras de utilizar o principal resíduo do município de Indaial, oriundo das indústrias de confecção.

Figura 8: workshop na RFCC de Indaial

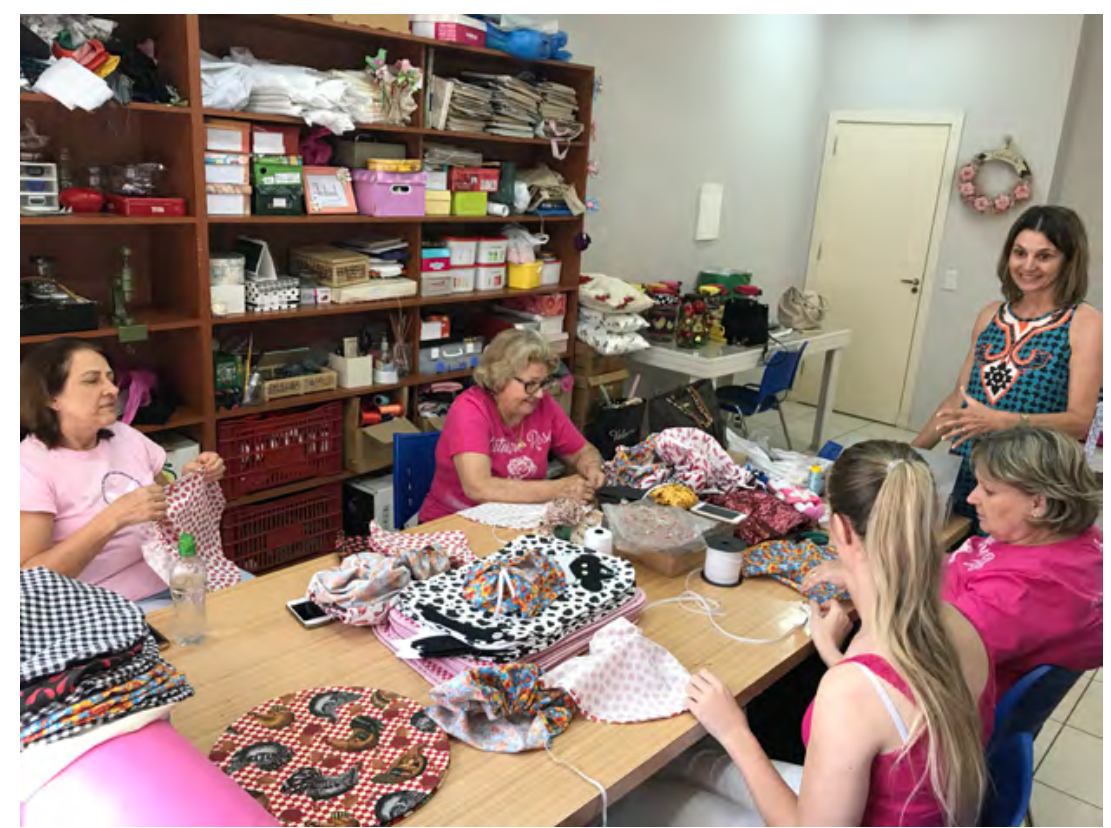

Fonte: fotografia produzida pelas Autoras em 2017.

Considerando que o grupo de voluntárias é pequeno, a participação de todas foi de extrema importância para a conclusão com êxito da atividade. Levou-se em consideração o conhecimento e a experiência do grupo, pois as competências e habilidades acumuladas pelas voluntárias contribuiram com ideias e auxiliaram no processo de confecção dos produtos, muitas vezes simplificando processos.

Sanders (2012) afirma que a experiência participativa não é simplesmente um método ou um conjunto de metodologias, mas sim o conhecimento e o desejo das pessoas. Dessa maneira houve um processo de cocriação por parte das voluntárias ao proporem alternativas na construção dos produtos, reduzindo processos e otimizando etapas na confecção de maneira mais rápida e fácil, além de apresentarem novas propostas de produtos a serem produzidos com o material cedido pelas confecções.

A fase de entrega/prototipação, de acordo com Vianna et al. (2012), tem como função auxiliar a validação das ideias geradas; apesar de ser 
apresentada como uma das últimas fases do processo de Design Thinking, pode ocorrer ao longo do projeto em paralelo à Imersão e à Ideação.

No processo aqui apresentado, após o workshop as voluntárias do RFCC produziram quatro tapa-olhos, seis marca-páginas modelo 1 e dez marca-páginas modelo 2.

A figura 9 mostra o resultado dos produtos confeccionados pelas voluntárias.

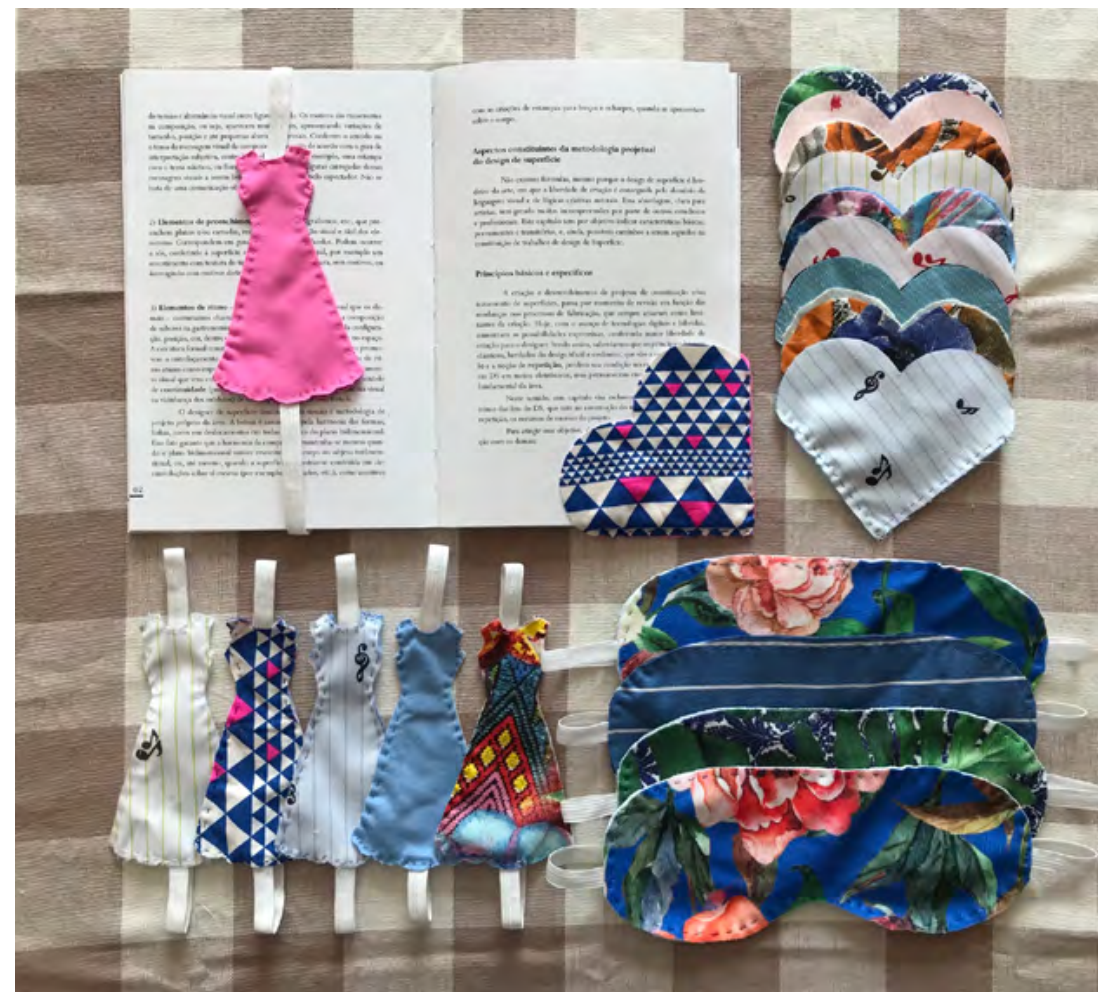

Fonte: fotografia produzida pelas Autoras em 2017.

Posteriormente à confecção dos produtos, foi feito o contato com a FIC para auxiliar a RFCC na divulgação do projeto. Identificou-se no calendário de eventos do município que a melhor opção para a RFCC era participar da feira Bummeln, realizada no segundo sábado de cada mês com o apoio da Associação Indaialense de Artesãos e da Prefeitura Municipal. A feira comercializa produtos de diversos segmentos, como artesanatos, trabalhos manuais, antiguidades, colecionáveis e brechó de roupas, além de ter atividades culturais como música, literatura e gastronomia de rua. A data escolhida para a participação do Artesanato Rosa na feira da Av. Beira Rio foi o dia 9 de setembro de 2017, conforme demonstra a figura 10 . 
Figura 10: Feira Bummeln (1. Vista da Av. Beira Rio com os estandes; 2. Estande da RFCC; 3 e 4. Produtos confeccionados pelas voluntárias em exposição)

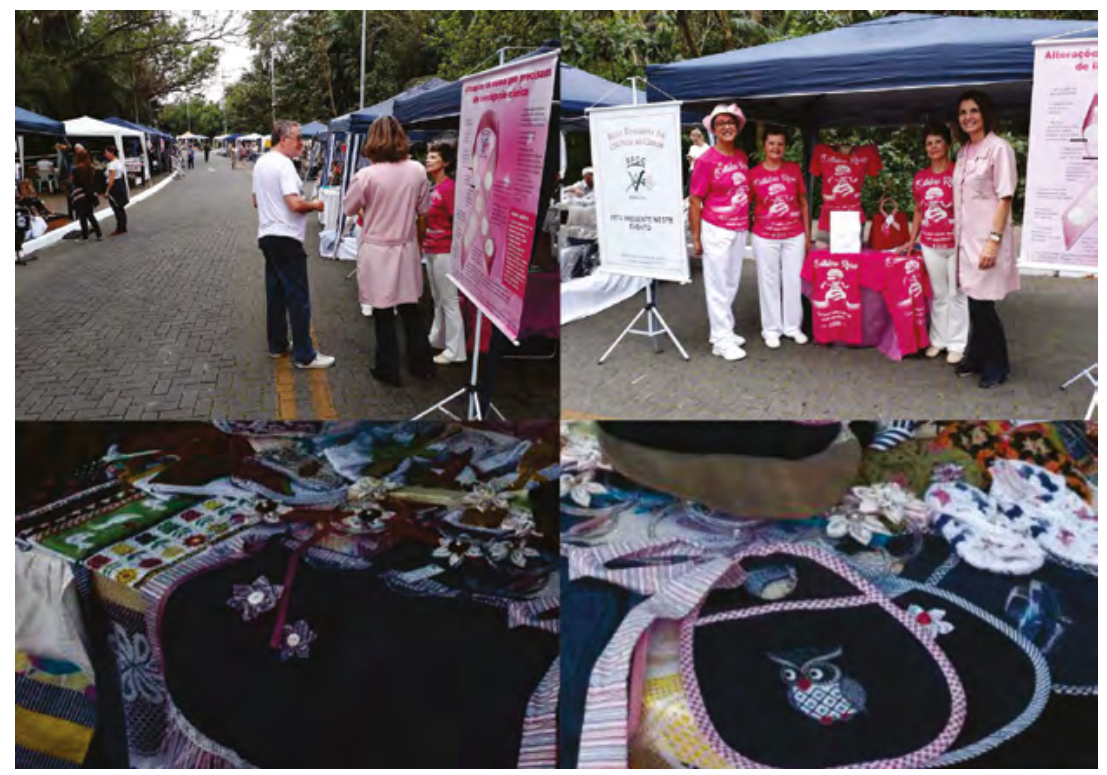

Fonte: fotografia produzidas pelas Autoras em 2017.

0 desafio de participar de um evento de grande visibilidade no municipio foi muito grande e, na ocasião, observou-se a relevância de demonstrar para a sociedade os trabalhos realizados pela RFCC, como a coleta gratuita de material para o exame Papanicolau, a drenagem linfática em pacientes mastectomizadas e 0 atendimento voluntário de profissionais da saúde. A comercialização de camisetas da campanha Outubro Rosa, além de ter a renda revertida para a ONG, busca conscientizar a população sobre a prevenção do câncer de mama e, oportunamente, a divulgação dos produtos desenvolvidos com o resíduo têxtil criou uma nova oportunidade para a RFCC buscar recursos financeiros para sua sustentabilidade.

Destaca-se que a participação em feiras é fundamental para a RFCC, pois é uma oportunidade para a divulgação de produtos e serviços oferecidos pela ONG e para a comercialização dos produtos fora da sede da RFCC.

Segundo Deheinzelin (2006), a economia criativa está baseada na construção de recursos intangíveis, como cultura e turismo, proporcionando uma sociedade mais sustentável, pois prioriza-se empreendedores culturais. A FIC proporcionou visibilidade ao possibilitar a participação da RFCC na feira de rua com os produtos desenvolvidos a partir da troca de competências e habilidades com a instituição de ensino.

Após concluída toda interlocução com os quatro atores do presente projeto, foi sintetizado em um infográfico, apresentado na figura 11, o fluxo da parceria estabelecida, que conta com participação ativa dos 
representantes das entidades, e cujo êxito se deu pela efetividade do projeto, pelo comprometimento, pelo estímulo e pela experiência de todos os envolvidos, reforçando a necessidade de ações que promovam a sustentabilidade, tema que vem sendo discutido cada vez mais em todos os setores.

Figura 11: fluxo de parceria

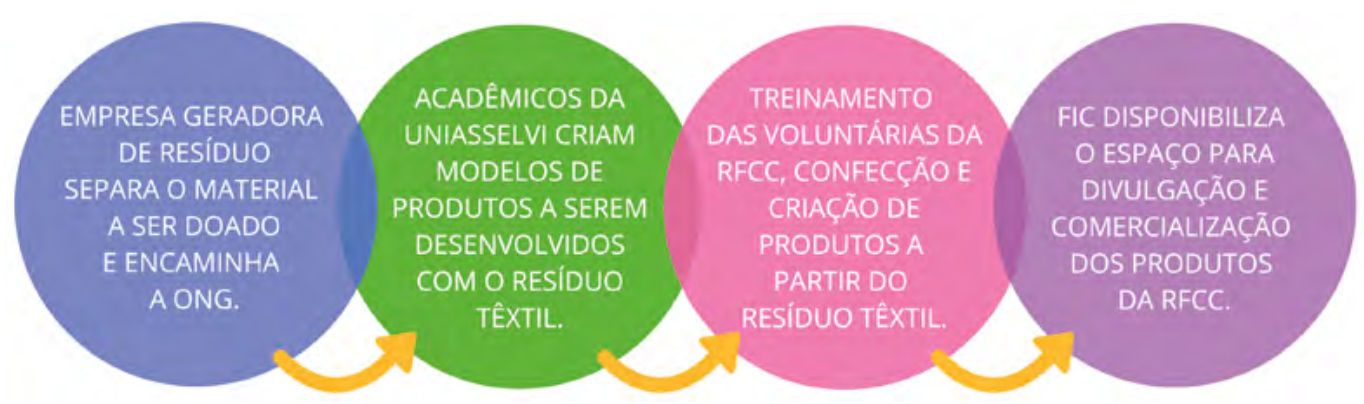

Fonte: elaborado pelas Autoras.

De maneira a aproximar ainda mais as empresas do município de In239 daial envolvidas no projeto e a RFCC, e para divulgar e sensibilizar pontualmente essa ação, buscou-se a Associação Empresarial de Indaial (ACIDI), inserindo um novo ator na cadeia. Foram analisadas formas de divulgação do projeto desenvolvido pela pesquisadora entre os associados, pois a ACIDI demonstrou proatividade nessa divulgação, envolvendo a agência Singular Comunicação. A partir das informações, a agência criou um nome, uma logo, o slogan para o projeto e o material a ser encaminhado via e-mail a todos os 356 associados (figura 12), que receberam a iniciativa de maneira positiva e muitos demonstraram interesse em iniciar a separação do material para ser doado à RFCC. 
Figura 12: informe enviado por e-mail aos associados da ACIDI

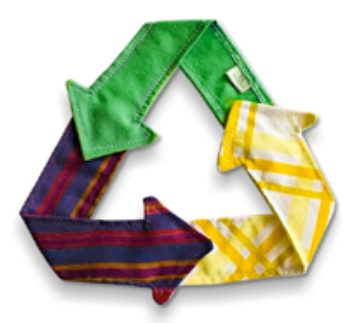

Projeto

PANO PRA

MANGA

AC̣ÃO SOLIDÁRIA EM PROL

DÁ REDE FEMININA

Mudar o destino das mulheres através da prevenção ao cânce de mama é a principal função do Rede Feminina de Combate ao Câncer. Mas há outro destino que pode ser mudado, e você pode nos ajudar.

\section{DOE SOBRAS DE TECIDOS PARA A REDE FEMININA. \\ (Tecidos leves com mais de $50 \mathrm{~cm}^{2}$ )}

A ACIDI, a FIC e o curso de moda A ACIDI, a da Uniasselvi darao nova forma aos residuos doados, com a confecção de artesanato, com muita criatividade e senso de sustentabilidade. As peças serão comercializadas na RFCC com todo o lucro revertido à própria instituição.

Simultaneamente evita-se que toneladas de resíduos sejam descartadas no lixo comum e promove-se ladas nolixo comune promove-se uma nova forma de contribuir financeivas ares de mulheres.

Confira as parcerias que já estão dando pano pra manga! - CHIA DL LAÇO CONHEÇÓLS - Ho CONFEçóes - PARADO NOAR - zERO GRAU

- Protótipo conftecétes

- SCHÖNe MODE

TONATUA CONFEcçō

Entre em contato com a RFCC ou com Caroline

$\begin{array}{rl}47999030892 & 0.92\end{array}$

\section{$\frac{R F C C}{V A C}$ ?}

Apoio:

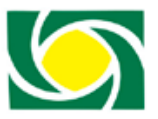

ACIDI 
Analisando todo ciclo finalizado, bem como a parceria estabelecida com a ACIDI, percebe-se que o resultado final da articulação definida cumpriu todas as etapas firmadas e evidenciou as potencialidades dos atores.

\section{Proposta de gestão}

Para o desenvolvimento da proposta de gestão, foram estudados os autores Ambrose e Harris (2011) e Vianna et al. (2012) para Design Thinking; Santa Rosa (2013) e Pinheiro e Alt (2011) para workshop; Schuler e Namioka (1993) e Sanders (2002) para Design Participativo; Deheinzelin (2006) para economia criativa e fluxonomia 4D.

Toda proposta foi elaborada para estimular a participação dos diversos setores do município, buscando a sustentabilidade do projeto. Portanto, o resultado dessa pesquisa aplicada é um método de trabalho, concebido para envolver diversos atores, desde a captação da matéria-prima até o produto final comercializado. Vale ressaltar que todo processo descrito só é possivel se a colaboração for a mola propulsora de todas as atividades propostas.

Dessa maneira, a primeira etapa condiz com a palavra prospecção, que inicia com a seleção das empresas geradoras de resíduos que possam ser reutilizados em um novo produto que tenha valor comercial. Em seguida, 0 resíduo deve ser separado para posterior cessão à RFCC. É importante que o resíduo seja entregue à ONG na forma de doação, sem que a empresa tenha vantagem comercial nesta etapa, outrora sim, o benefício de dar um novo destino a parte do resíduo gerado pela empresa.

De posse do material, a segunda etapa, que se refere à instituição de ensino, foi definida com a palavra investigação, pois aqui se faz necessário o auxílio do corpo discente e docente. É de responsabilidade da instituição analisar todo o material doado pelas empresas e entender as possiveis aplicações. Nesta etapa ocorre também o processo criativo por meio de ferramentas do design para criação de produtos com valor comercial, além da prototipação dos artefatos, utilizando as instalações e laboratórios da instituição. Em seguida é organizada a capacitação dos voluntários da ONG por meio de workshops de cocriação para o desenvolvimento dos produtos a partir das habilidades e conhecimentos do grupo, pois o compartilhamento dos saberes é de extrema importância nesta etapa.

$\mathrm{Na}$ terceira etapa, definida como concepção, o grupo de voluntários confecciona os produtos no ateliê da ONG. Caso a sede não disponha de estrutura para produção, uma parceria pode ser estabelecida com a instituição de ensino, desde que autorizada pelas partes.

A quarta etapa denomina-se divulgação. A parceria com associações empresariais do município que possam ser responsáveis pelo 
material visual e gráfico, bem como a divulgação da iniciativa na comunidade empresarial, são fundamentais para se obter novas parcerias com fornecedores de resíduos.

A quinta e última etapa remete à palavra exposição, concluindo o ciclo, cuja participação de um órgão do primeiro setor, município, traz toda a extensão desse trabalho, abrindo espaço e fomentando a propagação do projeto por meio da participação da ONG em eventos municipais, regionais, estaduais, nacionais e internacionais.

Após desenvolvidas as cinco etapas do método, o processo foi estruturado em um infográfico, conforme demostrado na figura 13.

Figura 13: proposta do método

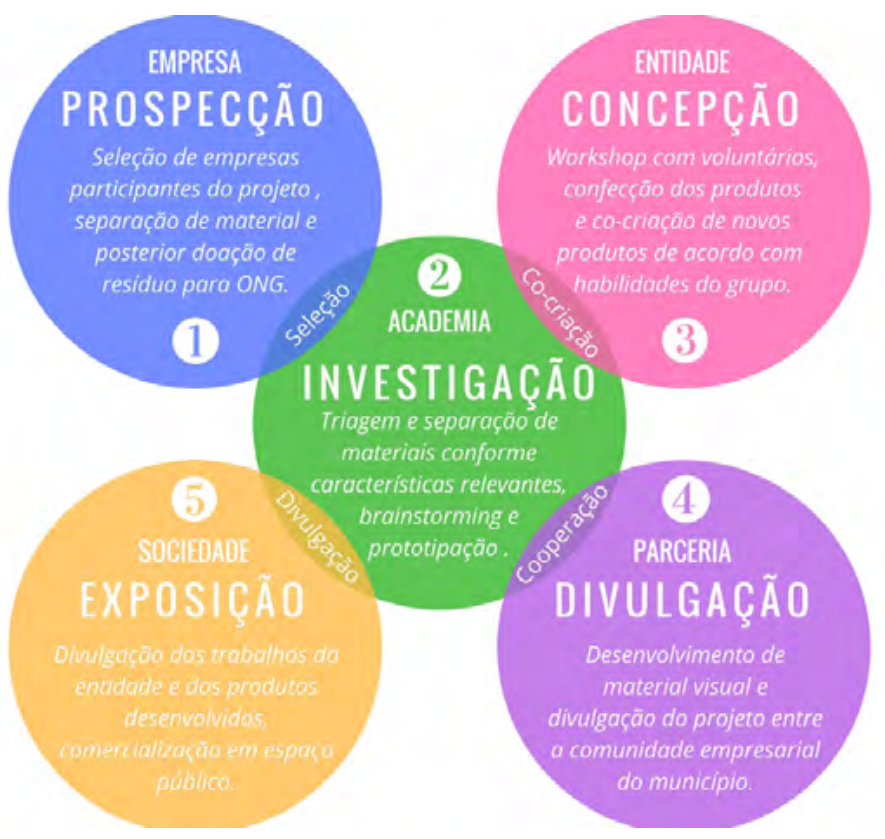

Fonte: elaborado pelas Autoras (2018).

Observa-se, portanto, que as empresas de confecções encontram um novo destino para parte do resíduo gerado na produção, a universidade coopera com a análise do material e o processo criativo, a ONG produz os artefatos para a comercialização, o que contribui para sua sustentabilidade, a ACIDI divulga a iniciativa para a comunidade empresarial e a FIC incentiva a RFCC em eventos culturais no município. Essa sistematização origina a economia do "cuidar".

Essa proposta de gestão é orientada por um método para contribuir com diversos tipos de trabalho: social, auxiliando a RFCC; ambiental, na reutilização de parte do resíduo gerado pelas confecções; cultural, no incentivo aos hábitos e costumes do município; financeiro, proporcionando a manutenção e continuidade de todo trabalho. 


\section{Considerações finais}

Tendo em vista que o objetivo principal da presente pesquisa aplicada foi articular por meio da gestão de design um processo de cooperação entre a ONG Rede Feminina de Combate ao Câncer (RFCC) de Indaial e as indústrias de confecção da região de Indaial, o Centro Universitário Leonardo Da Vinci (Uniasselvi) e a Fundação Indaialense de Cultura (FIC), conclui-se que os objetivos foram alcançados.

0 estudo demonstrou que a reutilização dos resíduos têxteis para criação de novos produtos, propiciada pela capacidade de costura das voluntárias da RFCC, pode gerar um ativo de valor ambientalmente correto e comercial, ajudando a sustentabilidade da entidade. Desta forma foi possivel disseminar uma maior consciência ambiental, motivando a participação dos atores envolvidos neste projeto em um ciclo virtuoso.

A gestão do design proposta apresenta-se como uma alternativa viável para coordenar um processo integrando as diversas entidades. Os temas relacionados ao campo do design, da inovação social, da gestão do design, da sustentabilidade e da economia criativa foram importantes para fundamentar o trabalho e estruturar um diálogo entre os atores envolvidos a fim de atingir os objetivos estratégicos que visam a manutenção economicamente sustentável da RFCC, a minimização do impacto ambiental dos resíduos têxteis das indústrias de confecção de Indaial, além da capacitação promovida pela Uniasselvi, representada pelo curso Design-Moda, bem como a promoção e valorização das ações desenvolvidas pela RFCC em parceria com a Fundação Indaialense de Cultura.

A relação estabelecida entre: as indústrias têxteis, por meio da disponibilização dos resíduos de malha e tecido; a RFCC, com atuação marcante no voluntariado e no desenvolvimento de trabalhos manuais; a FIC, com a representatividade perante o municipio e atuação no fomento a cultura; e a Uniasselvi, com a participação de docentes e discentes na prática sustentável e criativa do projeto, demostrou que, unindo essas frentes, é possivel uma sinergia com grande potencial econômico, ambiental e social.

Para a coordenadora e professora do curso de Design-Moda da Uniasselvi, a pesquisa empreendida propiciou um maior engajamento do curso com as questões sociais, além de uma aproximação da instituição com a comunidade. Destaca-se 0 interesse da instituição em dar continuidade ao presente projeto de mestrado em outras instituições da cidade, inclusive em municípios vizinhos nos quais a Uniasselvi atua.

Importante ressaltar alguns pontos positivos em algumas etapas: 1) abertura de contato da RFCC de Indaial com um maior número de confecções do município, possibilitando futuras doações e parceria para outros projetos como a campanha Outubro Rosa, a Caminhada Rosa, entre outros; 
2) desenvolvimento de produtos com materiais diferentes dos normalmente utilizados pelas voluntárias; 3 ) envolvimento de discentes no processo criativo para ajudar as voluntárias a criar e confeccionar produtos que anteriormente nem imaginavam produzir.

0 espaço para a comercialização dos produtos oportunizado pela FIC em um evento de grande visibilidade no município abriu as portas da instituição tanto para o trabalho social que ela já realiza, bem como para a exposição de trabalhos confeccionados pelo grupo de voluntárias. 0 envolvimento da FIC fortalece e incentiva a expressão cultural, além de estimular a promoção e valorização dos produtos desenvolvidos pela RFCC.

A participação da ACIDI resultou na divulgação entre os associados do projeto denominado "Pano pra Manga", idealizado pela agência de comunicação Singular, trazendo resultados ainda mais positivos.

0 desenvolvimento de um modelo de gestão de design com base nos conceitos da economia criativa demonstra a sustentabilidade econômica, ambiental e social do processo. 0 modelo é composto por cinco etapas, nas quais são descritas as ações que podem ser realizadas por cada ator em determinada fase.

Dessa maneira, o projeto alcançou o resultado esperado respondendo ao problema de pesquisa com a estruturação de uma articulação para a valorização e geração de renda para a RFCC por meio da gestão de design. 0 método proposto procurou extrair de cada ator envolvido o potencial necessário para viabilização do projeto, estreitou laços e efetivou parcerias.

Acredita-se, portanto, que a presente pesquisa aplicada pode ser replicada, independentemente da localidade ou região no país, tendo em vista que o descarte de materiais é uma prática comum nas empresas e a necessidade de auxiliar entidades como a RFCC é constante, o que torna esta iniciativa de grande impacto social.

Recebido em: 26-04-2018

Aprovado em: 07-08-2018 


\section{NOTA}

1 Disponivel em: http://plataformabrasil.saude.gov.br/visao/pesquisador/gerirPesquisa/ gerirPesquisaAgrupador.jsf. Acesso em: 24 abr. 2018.

\section{REFERÊNCIAS}

ALVES, Breno Castro. 0 futuro é 4D e o dinheiro não é tudo: conheça os desafios da rede Fluxonomia, da futurista Lala Deheinzelin. Draft, 10 nov. 2015. Seção Negócios Criativos. Disponivel em: https://projetodraft.com/o-futuro-e-4d-e-o-dinheiro-nao-e-tudo-conheca-os-desafios-darede-fluxonomia-da-futurista-lala-deheinzelin/. Acesso em: 16 abr. 2017.

AMBROSE, Gavin; HARRIS, Paul. Design thinking: s.m. ação ou prática de pensar o design. Tradução Mariana Belloli. Porto Alegre: Bookman, 2011.

ARAÚJO, Márcio Augusto. Produtos ecológicos para uma sociedade sustentável. In: Instituto para o Desenvolvimento da Habitação Ecológica (IDHEA). São Paulo: 2013.

BORGES, Adelia. Design + Artesanato: o caminho brasileiro. São Paulo: Terceiro Nome, 2011.

DEHEINZELIN, Lala. Contexto global atual, economia criativa e colaborativa, mar 2013. Disponivel em: https://www.academia.edu/4247860/CONTEXTO_GLOBAL_ATUAL_ECONOMIA_CRIATIVA_E COLABORATIVA Acesso em: 17 maio 2017.

. Economia criativa e empreendedorismo cultural, maio de 2006. Disponivel em: https:// www.researchgate.net/publication/265112107_ECONOMIA_CRIATIVA_E_EMPREENDEDORISMO_ CULTURAL Acesso em: 23 maio 2017.

FREITAS, Simone Araújo de; SILVA, Karla Alcione da; PECCINI, Alejandro Alvarado. Caracterização dos Resíduos Sólidos Gerados por Indústrias de confecção. In: CONGRESSO BRASILEIRO DE GESTÃO AMBIENTAL, 3., 2012, Goiânia. Anais eletrônicos... Goiânia: IBEAS, 2012. Disponivel em: http:// www.ibeas.org.br/congresso/Trabalhos2012/III-006.pdf. Acesso em: 23 maio 2017.

GIL, Antônio Carlos. Métodos e técnicas de pesquisa social. 3. ed. São Paulo: Atlas, 1991.

MADEIRA, Mariana Gonçalves. Economia criativa: implicações e desafios para a política externa brasileira. Brasilia: FUNAG, 2014.

MANZINI, Ezio. Design para a inovação social e sustentabilidade: Comunidades criativas, organizações colaborativas e novas redes projetuais. Rio de Janeiro: E-papers, 2008.

MESACASA, Andréia. A indústria de confecção do vestuário do município de Paro Branco: aspectos de desenvolvimento, gestão, design e proposta de reaproveitamento dos resíduos têxteis. 279 f. Dissertação (Mestrado em Desenvolvimento Regional)-Universidade Tecnológica Federal do Paraná, Pato Branco, 2012. Disponivel em: http://repositorio.utfpredu.br/jspui/handle/1/309. Acesso em: 26 out. 2018.

NEWBIGIN, John. A economia criativa: um guia introdutório. Reino Unido: Britsh Council, 2010.

OKABE, Marcio. Fluxonomia 4D. 3 abr. 2016. 1 gif, color. Disponivel em: http://marciookabe.com.br/ fluxonomia-4d/fluxonomia-4d/. Acesso em: 16 abr. 2017.

PINHEIRO, Tennyson; ALT, Luis. Design thinking Brasil: empatia, colaboração e experimentação para pessoas, negócios e sociedade. 1 ed. Rio de Janeiro: Elsevier, 2011.

PORTAL BRASIL Empreendedorismo social gera lucro e desenvolvimento, 1 fev. 2012. Cidadania e Justiça. Disponivel em: http://www.brasil.gov.br/cidadania-e-justica/2012/02/empreendedorismosocial-gera-lucro-e-desenvolvimento. Acesso em: 23 maio 2017. 
PROGRAMA DO ARTESANATO BRASILEIRO (PAB). Base conceitual do artesanato brasileiro. Brasilia: Ministério do Desenvolvimento, Indústria e Comércio Exterior, 2012.

SANDERS, Elizabeth B.-N. From User-Centered to Participatory Design Approaches. In: FRESCARA, Jorge. (Ed.). Design and the Social Sciences: Making Connections. London: Taylor \& Francis Books Limited, 2002. p. 18-25. Disponivel em: http://www.maketools.com/articles-papers/ FromUsercenteredtoParticipatory_Sanders_\%2002.pdf. Acesso em: 9 jul. 2017.

SANTA ROSA, José Guilherme. Ergodesign participativo: um possivel caminho para a Inovação no Design de Interfaces, produtos, ambientes, senviços e processos. In: BARBOSA, Ana Cristina L S.; RANGEL, Márcia Moreira; RAPOSO, Myrtes (Org.). Ergonomia Design Usabilidade Interação. 1. ed. Juiz de Fora: MAMM/UFJF, 2013.

SANTOS-DUISENBERG, Edna dos. Economia criativa como estratégia de desenvolvimento: uma visão dos países em desenvolvimento. São Paulo: Caderno Itaú Cultural, 2008.

SCHULER, Douglas; NAMIOKA, Aki. Participatory Design: Principles and Practices. New Jersey: CRC Press, 1993.

SEBRAE. 0 que é economia criativa. Disponivel em: http://www.sebrae.com.br/sites/PortalSebrae/ artigos/o-que-e-economia-criativa,3fbb5edae79e6410VgnVCM2000003c74010aRCRD. Acesso em: 30 set. 2016.

SINGULAR COMUNICAÇÃO. Projeto Pano pra Manga. Comunicado enviado por e-mail. 2018. 1 imagem digital, color.

VIANNA, Mauricio et al. Design Thinking: Inovação em negócios. 1. ed. Rio de Janeiro: MJV Press, 2012. Disponivel em: https://cdn2.hubspot.net/hubfs/455690/Ofertas/E-books/Arquivos/Livro_ Design_Thinking_-_Inovao_Negcios.pdf. Acesso em: 14 fev. 2018. 